\title{
Bifunctional Rhodium Intercalator Conjugates as Mismatch-directing DNA Alkylating Agents
}

\author{
Ulrich Schatzschneider and Jacqueline K. Barton * \\ Division of Chemistry and Chemical Engineering, California Institute of Technology, Pasadena, CA 91125 \\ jkbarton@caltech.edu
}

Supporting Information

Synthesis and characterization of conjugate 1 and intermediates

Scheme S1 - Synthesis of tris-heteroleptic rhodium complexes

Scheme S2 - Synthesis of an amino-functionalized bipyridine ligand

Scheme S3 - Introduction of the aminoalkyl-substituted bipyridine to the rhodiumchrysenequinone diimine complex

Scheme S4 - Synthesis of a carboxy-functionalized aniline mustards

Literature 


\section{Synthesis and characterization of conjugate 1 and intermediates}

Conjugate 1 of $\left[\mathrm{Rh}(\text { phen)(chrysi)(bpy) }]^{3+}\right.$ tethered to an aniline mustard was prepared in a thirdteen step sequence as outlined in Schemes S1 to S4.

[Rh(phen)(chrysi)( $\left.\left.\mathrm{NH}_{3}\right)_{2}\right]^{3+} \mathbf{2}$ was synthesized in four steps from rhodium trichloride, phenanthroline, and 5,6-chrysenequinone, and purified as described by Mürner, Jackson, and Barton (Scheme S1). ${ }^{[1]}$

The synthesis of the aminoalkyl-functionalized bipyridine 6 is shown in Scheme S2. The mono-anion of 4,4'-dimethylbipyridine, obtained by deprotonation of $\mathbf{3}$ with one equivalent of freshly prepared lithium diisopropylamine, was reacted with an excess of 1,6dibromohexane under carefully controlled conditions. ${ }^{[2,3]}$ After aqueous workup and column chromatography on silica with a gradient of dichloromethane and diethylether, 4-(7bromoheptyl)-4'-methylbipyridine 4 was obtained in $58 \%$ yield. This was converted to phthalimide 5 in almost quantitative yield by reaction with potassium phthalimide followed by cleavage to 4-(7-aminoheptyl)-4'-methylbipyridine 6 with hydrazine monohydrate in methanol. ${ }^{[4]}$

Aminoalkyl-substituted bipyridine 6 was then reacted with $\left[\mathrm{Rh}(\right.$ phen $)\left(\text { chrysi) }\left(\mathrm{NH}_{3}\right)_{2}\right]^{3+} \mathbf{2}$ in anhydrous acetonitrile at elevated temperature to give $\left[R h(p h e n)\left(\text { chrysi)(bipy }{ }^{\#}\right]^{3+} \mathbf{7}\right.$ in 43 $\%$ yield after purification on Sephadex SP C25 (Scheme S3).

The aniline mustard 12 was prepared in four steps from 4-aminophenol 8 as outlined in Scheme S4. ${ }^{[5-7]}$ The starting material was reacted with bromoacetic acid ethyl ester and separated from other alkylation products by column chromatography on silica to give 9 . This compound was then reacted with oxirane to give (4-(N,N-bis(2-hydroxy-ethyl)phenoxy)acetic acid ester 10. The hydroxy groups were substituted by chlorides upon treatment with phosphoroxytrichloride in benzene to give $\mathbf{1 1}$ and the ester protective group then removed under acidic conditions to yield 12.

Conjugate 1 was then prepared by coupling of 7 with 12 in anhydrous dimethylformamide in the presence of EDAC (1-ethyl-3-(3-dimethylaminopropyl)carbodiimide) and HOBt (1-hydroxybenzotriazol) as shown in Scheme 1 and finally purified by semipreparative HPLC. 
Scheme S1. Synthesis of tris-heteroleptic rhodium complexes.

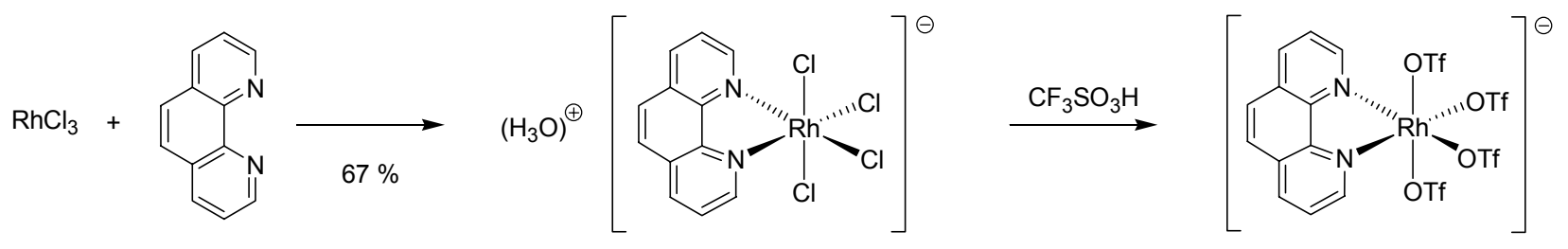

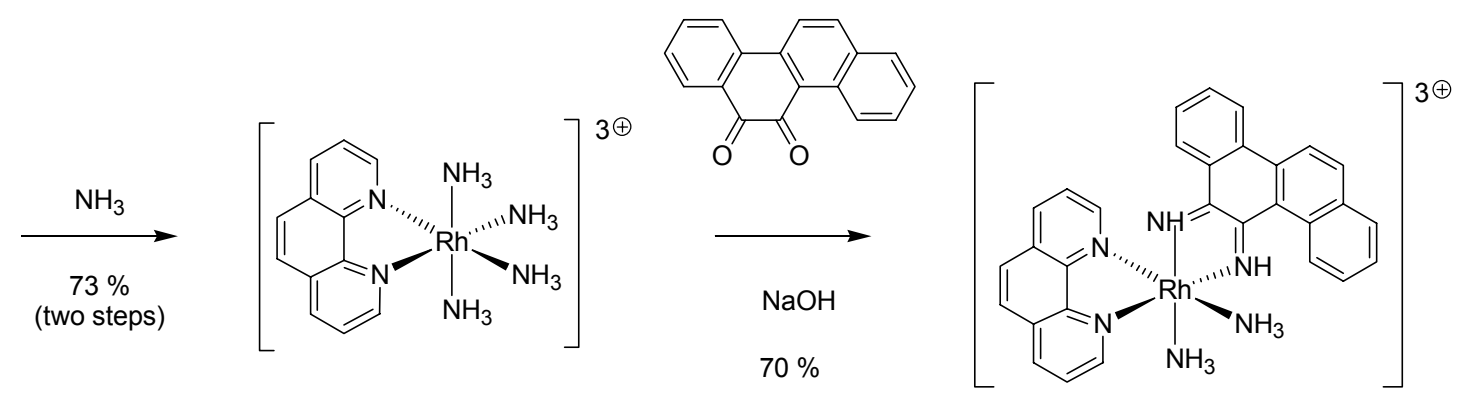


Scheme S2. Synthesis of an aminoalkyl-functionalized bipyridine ligand.

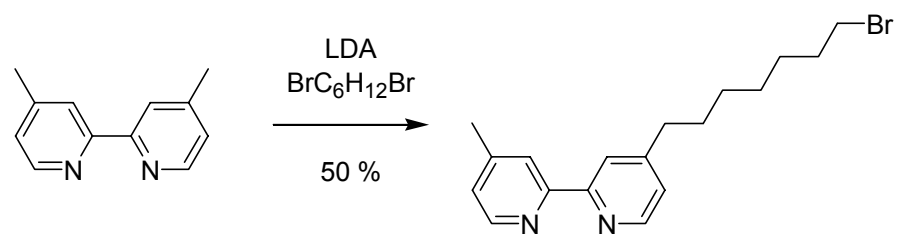

3

4
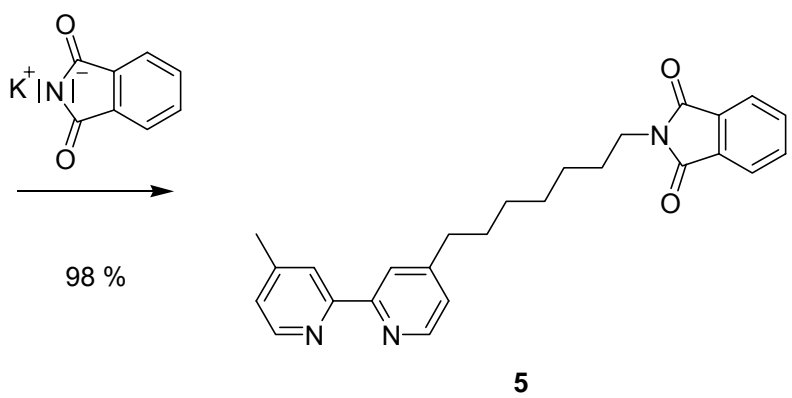

$\stackrel{\mathrm{N}_{2} \mathrm{H}_{4}}{\longrightarrow}$

$76 \%$

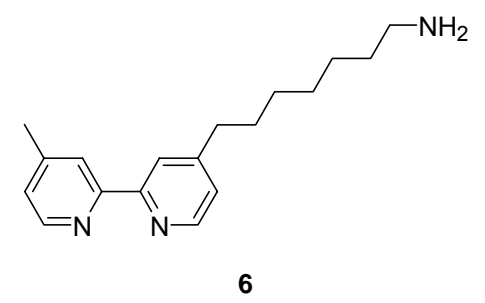


Scheme S3. Introduction of the aminoalkyl-substituted bipyridine to the rhodiumchrysenequinone diimine complex.
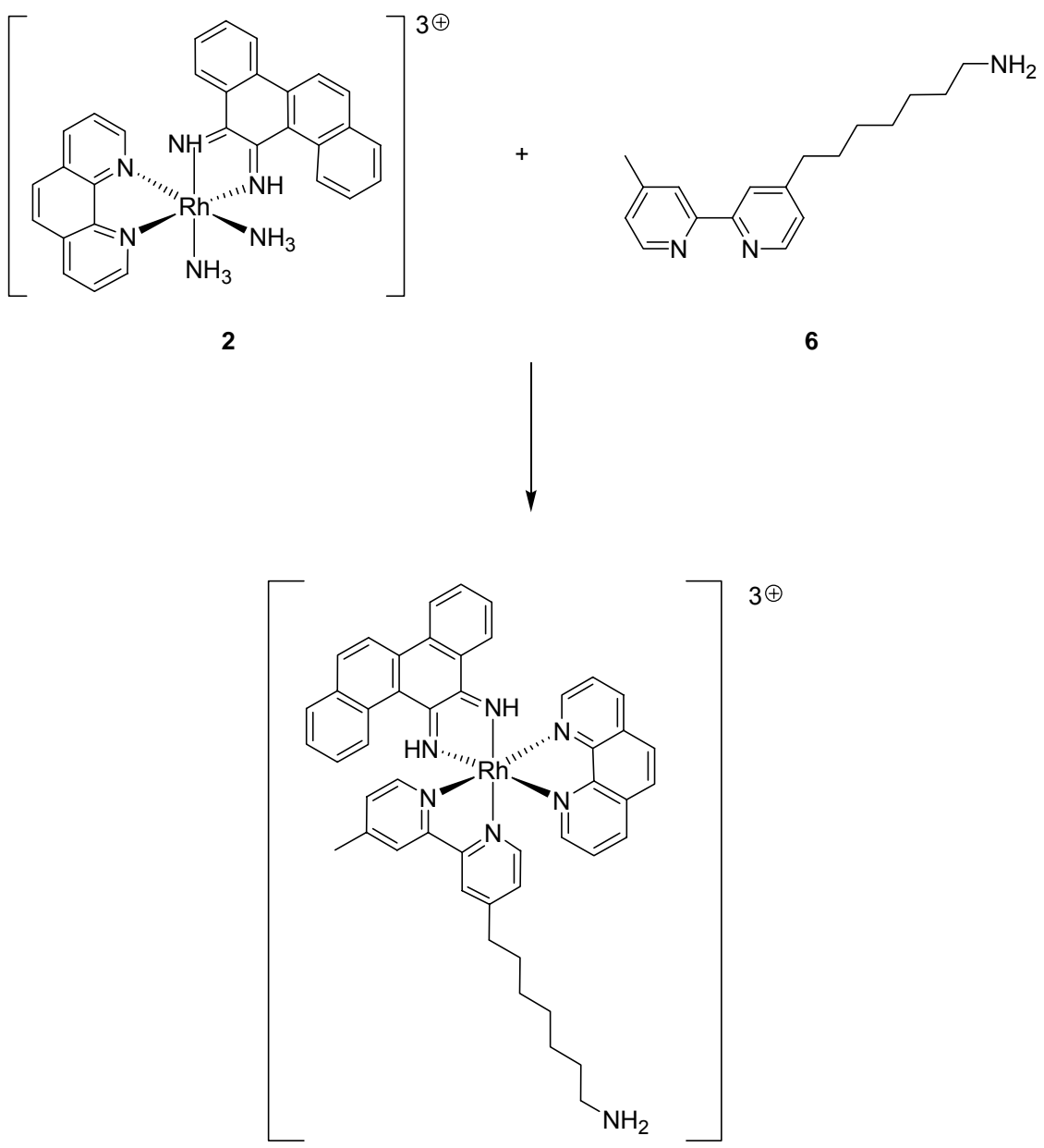

7 
Scheme S4. Synthesis of a carboxy-functionalized aniline mustard.

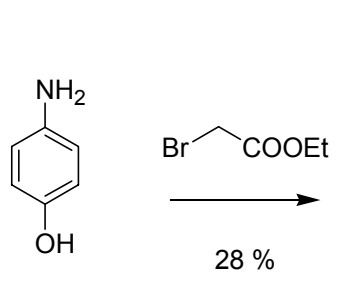

8

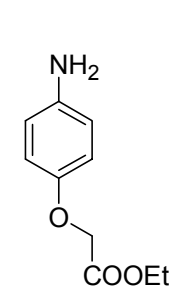

9

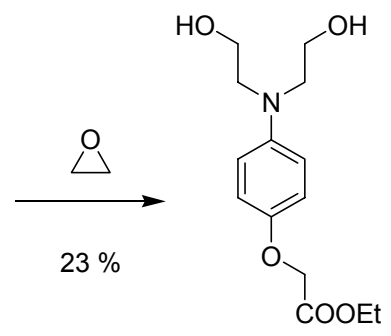

10

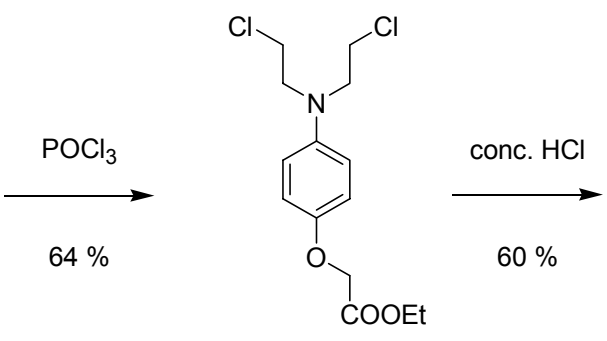

11

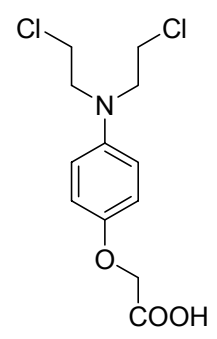

12 


\section{Synthetic procedures and characterization}

\section{4-(7-Bromoheptyl)-4'-methylbipyridine 4}

Anhydrous tetrahydrofuran $(25 \mathrm{ml})$ was placed in a dry Schlenk bottle under argon and cooled to $-78{ }^{\circ} \mathrm{C}$ with an acetone/dry ice mixture. Then diisopropylamine $(4.6 \mathrm{ml}, 32.8$ $\mathrm{mmol}$ ) was added via syringe followed by $n$-butyllithium (15\% solution in hexane, 17.2 $\mathrm{ml}, 27.4 \mathrm{mmol}$ ) to give a slightly yellow solution which was kept at $-78{ }^{\circ} \mathrm{C}$. In a separate Schleck bottle, 4,4'-dimethylbipyridine $(5.0 \mathrm{~g}, 27.2 \mathrm{mmol})$ was dissolved in anhydrous tetrahydrofuran $(150 \mathrm{ml})$, precooled to $-78{ }^{\circ} \mathrm{C}$ and then added to the former solution. The mixture, which turned deep brown, was stirred at that temperature for $1 \mathrm{~h}$ and then allowed to warm to $0{ }^{\circ} \mathrm{C}$ by placing in an ice bath. In another Schlenk bottle, 1,6dibromohexane $(20 \mathrm{ml}, 51.2 \mathrm{mmol})$ was dissolved in anhydrous tetrahydrofuran $(20 \mathrm{ml})$ at room temperature and then added to the former solution at once(!). The mixture first turned blue but the color changed to yellow within $1.5 \mathrm{~h}$ hours, after which the reaction was quenched by addition of water $(100 \mathrm{ml})$. After stirring for $30 \mathrm{~min}$, the $\mathrm{pH}$ was adjusted to $\mathrm{pH}=5$ and the mixture left to stand overnight. The yellow organic phase was separated, the aqueous phase extracted with ether $(100 \mathrm{ml})$ and dichloromethan $(2 \times 100$ $\mathrm{ml}$ ), and the combined organic phases washed with $5 \mathrm{M}$ sodium chloride, dried over magnesium sulfate, and the solvent removed in vacuo at room temperature(!). The slightly yellow oil obtained was purified by column chromatography on silica first with dichloromethane as the eluent to remove excess 1,6-dibromohexane, and then with a gradient of dichloromethane/ether $(100: 0 \rightarrow 0: 100)$. After removal of the solvent, the product was obtained as a white solid $(5.48 \mathrm{~g}, 15.78 \mathrm{mmol}, 58.0 \%) .{ }^{1} \mathrm{H}$ NMR $\left(\mathrm{CDCl}_{3}\right.$, $300 \mathrm{MHz}): \delta=8.55(\mathrm{t}, \mathrm{J}=4.8 \mathrm{~Hz}, 2 \mathrm{H}), 8.23(\mathrm{~m}, 2 \mathrm{H}), 7.13(\mathrm{~d}, J=4.8 \mathrm{~Hz}, 2 \mathrm{H}), 3.40(\mathrm{t}, J=$ $6.7 \mathrm{~Hz}, 2 \mathrm{H}), 2.69(\mathrm{t}, \mathrm{J}=7.8 \mathrm{~Hz}, 2 \mathrm{H}), 2.44(\mathrm{~s}, 3 \mathrm{H}), 1.84(\mathrm{~m}, 2 \mathrm{H}), 1.70(\mathrm{~m}, 2 \mathrm{H}), 1.37(\mathrm{~m}$, $6 \mathrm{H})$; MS(ESIpos): $369(\mathrm{M}+\mathrm{Na}), 347(\mathrm{M}+\mathrm{H}), 267(\mathrm{M}-\mathrm{Br})$.

\section{4-(7-phthalimidoheptyl)-4'-methylbipyridine 5}

4-(7-Bromoheptyl)-4'-methylbipyridine $4(0.70 \mathrm{~g}, 2.00 \mathrm{mmol})$ was dissolved in anhydrous dimethylformamide $(125 \mathrm{ml})$ and solid potassium phthalimide $(0.45 \mathrm{~g}, 2.40 \mathrm{mmol})$ was added to the slightly yellow solution. After stirring for $90.5 \mathrm{~h}$, the solution was diluted with chloroform $(80 \mathrm{ml})$ and then poured into water $(250 \mathrm{ml})$. The phases were separated and the aqueous phase extracted with chloroform $(2 \times 100 \mathrm{ml})$. The combined organic phases were washed with $0.2 \mathrm{M}$ sodium hydroxide $(100 \mathrm{ml})$, water, and brine, dried over magnesium sulfate, and the solvent removed to give the product as a colorless oil which solidified to a white solid upon standing $(0.81 \mathrm{~g}, 1.96 \mathrm{mmol}, 98.0 \%) .{ }^{1} \mathrm{H}$ NMR $\left(\mathrm{CDCl}_{3}, 300\right.$ $\mathrm{MHz}): \delta=8.53(\mathrm{~m}, 2 \mathrm{H}), 8.21(\mathrm{~m}, 2 \mathrm{H}), 7.83(\mathrm{~m}, 2 \mathrm{H}), 7.69(\mathrm{~m}, 2 \mathrm{H}), 7.12(\mathrm{~m}, 2 \mathrm{H}), 3.67(\mathrm{t}, \mathrm{J}$ $=7.2 \mathrm{~Hz}, 2 \mathrm{H}), 2.67(\mathrm{t}, \mathrm{J}=7.8 \mathrm{~Hz}, 2 \mathrm{H}), 2.43(\mathrm{~s}, 3 \mathrm{H}), 1.66(\mathrm{~m}, 4 \mathrm{H}), 1.36(\mathrm{~m}, 6 \mathrm{H})$; MS(ESIpos): $414(\mathrm{M}+\mathrm{H}), 436(\mathrm{M}+\mathrm{Na})$.

\section{4-(7-aminoheptyl)-4'-methylbipyridine 6}

Phthalimide 5 ( $0.81 \mathrm{~g}, 1.96 \mathrm{mmol})$ was dissolved in methanol $(50 \mathrm{ml})$ by heating to $70{ }^{\circ} \mathrm{C}$ to give a colorless solution. Then hydrazine monohydrate $(0.2 \mathrm{ml}, 4.1 \mathrm{mmol})$ was added and the reaction mixture stirred at $70{ }^{\circ} \mathrm{C}$ for $19 \mathrm{~h}$. The solvent was removed and $6 \mathrm{M}$ hydrochloric acid $(100 \mathrm{ml})$ added to the white solid obtained. The suspension was ex- 
tracted with chloroform, the organic phase washed with $6 \mathrm{M}$ hydrochloric acid $(60 \mathrm{ml})$, and the combined aqueous phases then adjusted to $\mathrm{pH}=8$ with $5 \mathrm{M}$ sodium hydroxide. The aqueous phase was extracted with chloroform and ether, the combined organic phases dried over magnesium sulfate and evaporated to dryness to give the product as a white solid (420 mg, $1.48 \mathrm{mmol}, 76 \%) .{ }^{1} \mathrm{H} \mathrm{NMR}\left(\mathrm{CDCl}_{3}, 300 \mathrm{MHz}\right): \delta=8.54(\mathrm{t}, \mathrm{J}=4.5$ $\mathrm{Hz}, 2 \mathrm{H}), 8.21(\mathrm{~m}, 2 \mathrm{H}), 7.13(\mathrm{~d}, \mathrm{~J}=4.8 \mathrm{~Hz}, 2 \mathrm{H}), 2.68(\mathrm{~m}, 4 \mathrm{H}), 2.43(\mathrm{~s}, 3 \mathrm{H}), 1.85(\mathrm{~s}, 2 \mathrm{H})$, $1.70(\mathrm{~m}, 4 \mathrm{H}), 1.39(\mathrm{~m}, 6 \mathrm{H})$; MS (ESIpos): $284(\mathrm{M}+\mathrm{H})$.

\section{$\left[\mathrm{Rh}\left(\right.\right.$ phen)(chrysi)(bipy $\left.\left.{ }^{\sharp}\right)\right] \mathrm{Cl}_{3} 7$}

4-(7-aminoheptyl)-4'-methylbipyridine $6(160.0 \mathrm{mg}, 0.56 \mathrm{mmol})$ was dissolved in anhydrous acetonitrile $(35 \mathrm{ml})$ and then $\left[\mathrm{Rh}(\right.$ phen $)\left(\right.$ chrysi) $\left.\left(\mathrm{NH}_{3}\right)_{4}\right] \mathrm{Cl}_{3} 2(226.6 \mathrm{mg}, 0.33 \mathrm{mmol})$, dissolved in $25 \mathrm{ml}$ of the same solvent with sonication, was added to the former solution. The mixture was heated to reflux under argon for $19.5 \mathrm{~h}$, cooled to room temperature, and the solvent removed to give a deep brown solid. The solid was dissolved in a minimum amount of $0.05 \mathrm{M}$ magnesium chloride and methanol and then loaded onto a column of Sephadex SP C25 $(20 \times 4 \mathrm{~cm})$ pre-equilibrated with $0.05 \mathrm{M}$ magnesium chloride and the product eluted with a gradient of $0.05 \rightarrow 0.5 \mathrm{M}$ magnesium chloride. All magnesium chloride solutions were acidified with a drop of hydrochloric acid. The main fraction was loaded on a $\mathrm{C}_{18}$ Waters SepPak $(10 \mathrm{~g})$ which was washed with cupious amount of water, and the product then eluted with acetonitrile containing a drop of trifluoroacetic acid. In order to obtain a more pure product (> $98 \%$ from HPLC), the purification procedure was repeated once. After removal of the solvent in a stream of air and drying in vacuo, the product was obtained as a red-brown solid $(131.4 \mathrm{mg}, 0.13 \mathrm{mmol}, 39.4 \%)$. MS (ESIpos): 820 ( $\left.\mathrm{M}^{+}-3 \mathrm{Cl}-2 \mathrm{H}\right), 410\left(\mathrm{M}^{2+}-3 \mathrm{Cl}-\mathrm{H}\right)$; UV/Vis (water): 212, 264, 298 (sh), 312 (sh), $398(6200) \mathrm{nm}\left(\mathrm{I} \mathrm{mol}^{-1} \mathrm{~cm}^{-1}\right)$; HPLC $(100: 0 \rightarrow 30: 70$ water/acetonitrile over $50 \mathrm{~min})$ $>98 \%$.

\section{(4-Aminophenoxy)acetic acid ethyl ester 9}

4-Aminophenol 8 (20.0 g, $183.3 \mathrm{mmol})$ was dissolved in ice-cold degassed anhydrous dimethylformamide $(250 \mathrm{ml})$ under argon and then solid sodium hydride $(55-65 \%$ in oil, $7.6 \mathrm{~g}, 190 \mathrm{mmol}$ ) was added in small portions. The solution was stirred at $0{ }^{\circ} \mathrm{C}$ for 30 min after which it had turned deep red-brown. Then bromoacetic acid ethyl ester $(20.2$ $\mathrm{ml}, 182.2 \mathrm{mmol}$ ) was slowly added at $0{ }^{\circ} \mathrm{C}$ via syringe and the resulting mixture stirred at room temperature overnight. After removal of the solvent, the resulting orange gum was dissolved in a mixture of ethylacetate and water (250 ml, 1:1), the organic phase separated, the aqueous phase extracted with ethyl acetate $(2 \times 100 \mathrm{ml})$, the combined organic phases washed with sodium hydrogencarbonate, brine, and water, drived over magnesium sulfate and the solvent removed. The resulting brown oil was purified twice by column chromatography on silica with chloroform/methanol $(9: 1)$ as the eluent to give the product as an orange oil which slowly solidified (9.83 g, $50.4 \mathrm{mmol}, 27.5 \%)$. ${ }^{1} \mathrm{H}$ NMR $\left(\mathrm{CDCl}_{3}, 300 \mathrm{MHz}\right): \delta=6.76(\mathrm{~d}, \mathrm{~J}=9.3 \mathrm{~Hz}, 2 \mathrm{H}), 6.62(\mathrm{~d}, \mathrm{~J}=9.0 \mathrm{~Hz}, 2 \mathrm{H}), 4.53(\mathrm{~s}, 2 \mathrm{H})$, 4.25 (q, J = 7.2 Hz, 2H), 1.29 (t, J = 7.2 Hz, 3H); MS (ESIpos): $196(\mathrm{M}+\mathrm{H}), 218(\mathrm{M}+\mathrm{Na})$. 


\section{(4-Bis(2-hydroxyethyl)aminophenoxy)acetic acid ethyl ester 10}

(4-Aminophenoxy)acetic acid ethyl ester $9(7.89 \mathrm{~g}, 40.4 \mathrm{mmol})$ was dissolved in a degassed mixture of acetic acid and water $(35 \mathrm{ml}, 1: 1)$ under argon to give a orange-to-red solution which was cooled to $0{ }^{\circ} \mathrm{C}$. Oxirane $(9.10 \mathrm{~g}, 206.6 \mathrm{mmol})$ was condensed into a separate Schlenk bottle immersed in acetone/dry ice and then added with a syringe precooled to $-20{ }^{\circ} \mathrm{C}$ to the former solution. The mixture was allowed to warm to room temperature while stirring under argon for $18.5 \mathrm{~h}$ and the deep brown solution then concentrated in vacuo at $<40{ }^{\circ} \mathrm{C}$. Water $(25 \mathrm{ml})$ was added to the resulting oily material and the product extracted with ether $(4 \mathrm{x} 100 \mathrm{ml})$. The combined organic phases were carefully washed neutral with $2 \mathrm{M}$ sodium hydrogencarbonate $(100 \mathrm{ml})$ in a large separation funnel (strong effervescence!) followed by water, dried over magnesium sulfate and the solvent then removed at $<40{ }^{\circ} \mathrm{C}$. The resulting material was twice recrystallized from toluene/hexanes (300 $\mathrm{ml}, 1: 1)$ to remove some brown oil and then purified by column chromatography on silica with chloroform/methanol (9:1) as the eluent. The product was obtained as a slightly pinkish oil which very slowly solidified to a white solid (2.58 g, 9.1 mmol, $22.5 \%$ ). ${ }^{1} \mathrm{H}$ NMR $\left(\mathrm{CDCl}_{3}, 300 \mathrm{MHz}\right): \delta=6.82(\mathrm{~d}, \mathrm{~J}=9.0 \mathrm{~Hz} \mathrm{~Hz}, 2 \mathrm{H}), 6.66(\mathrm{~d}, \mathrm{~J}=$ $9.0 \mathrm{~Hz}, 2 \mathrm{H}), 4.53(\mathrm{~s}, 2 \mathrm{H}), 4.24(\mathrm{q}, \mathrm{J}=7.1 \mathrm{~Hz}, 2 \mathrm{H}), 3.76(\mathrm{t}, \mathrm{J}=5.0 \mathrm{~Hz}, 4 \mathrm{H}), 3.45(\mathrm{t}, \mathrm{J}=$ $4.8 \mathrm{~Hz}, 4 \mathrm{H}), 1.28$ (t, $\mathrm{J}=7.1 \mathrm{~Hz}, 3 \mathrm{H})$; MS (ESIpos): $284(\mathrm{M}+\mathrm{H}), 306(\mathrm{M}+\mathrm{Na})$.

\section{(4-Bis(2-chloroethyl)aminophenoxy)acetic acid ethyl ester 11}

(4-Bis(2-hydroxyethyl)aminophenoxy)acetic acid ethyl ester $10(0.81 \mathrm{~g}, 2.86 \mathrm{mmol})$ was dissolved in anhydrous benzene $(10 \mathrm{ml})$ and then phosphoroxy trichloride $(0.8 \mathrm{ml}, 8.58$ $\mathrm{mmol}$ ) was added via syringe followed by heating to $100-110^{\circ} \mathrm{C}$ for $1 \mathrm{~h}$. Afterwards, the solution was poured on ice, the organic phase separated, dried over magnesium sulfate, and shaken with activated alumina. After removal of the solvent, the product was obtained as a colorless oil which solidified to a white solid $(0.58 \mathrm{~g}, 1.81 \mathrm{mmol}, 63.3 \%) .{ }^{1} \mathrm{H}$ NMR $\left(\mathrm{CDCl}_{3}, 300 \mathrm{MHz}\right): \delta=6.84(\mathrm{~d}, \mathrm{~J}=9.0 \mathrm{~Hz}, 2 \mathrm{H}), 6.62(\mathrm{~d}, J=9.3 \mathrm{~Hz} \mathrm{~Hz}, 2 \mathrm{H}), 4.52$ (s, 2H), 4.24 (q, J = 7.2 Hz, 2H), $3.59(\mathrm{~m}, 8 \mathrm{H}), 1.27$ (t, $J=7.2 \mathrm{~Hz}, 3 \mathrm{H}$ ); MS (ESIpos): 320 $(\mathrm{M}+\mathrm{H})$.

\section{(4-Bis(2-chloroethyl)aminophenoxy)acetic acid 12}

(4-Bis(2-chloroethyl)aminophenoxy)acetic acid ethyl ester $11(0.62 \mathrm{~g}, 1.94 \mathrm{mmol})$ was dissolved in concentrated hydrochloric acid $(10 \mathrm{ml})$, heated to reflux for $1 \mathrm{~h}$ and cooled to room temperature. After addition of water $(50 \mathrm{ml})$, the product was extracted into diethylether $(4 \times 50 \mathrm{ml})$, the combined organic phases wahsed with water, dried over magnesium sulfate, and the solvent removed to give a white solid $(0.34 \mathrm{~g}, 1.16 \mathrm{mmol}, 59.8$ $\%) .{ }^{1} \mathrm{H}$ NMR $\left(\mathrm{CDCl}_{3}, 300 \mathrm{MHz}\right): \delta=6.87(\mathrm{~d}, \mathrm{~J}=9.0 \mathrm{~Hz}, 2 \mathrm{H}), 6.65(\mathrm{~d}, \mathrm{~J}=9.3 \mathrm{~Hz}, 2 \mathrm{H})$, $4.60(\mathrm{~s}, 2 \mathrm{H}), 3.62(\mathrm{~m}, 8 \mathrm{H})$; MS (ESIpos): $292(\mathrm{M}+\mathrm{H})$. 


\section{[Rh(phen)(chrysi)(bipy)]Cl 3}

[Rh(phen)(chrysi)(bipy $\left.\left.{ }^{\#}\right)\right] \mathrm{Cl}_{3} 7(5.8 \mathrm{mg}, 6.2 \mu \mathrm{mol})$ was dissolved in anhydrous dimethylformamide under argon to give a bright orange solution. Then, (4-Bis(2chloroethyl)aminophenoxy)acetic acid $12(2.0 \mathrm{mg}, 6.8 \mu \mathrm{mol})$ was added as a solid followed by HOBt (1-hydroxybenzotriazol, $2.1 \mathrm{mg}, 15.5 \mu \mathrm{mol})$. Finally, EDAC (1-ethyl-3-(3dimethylaminopropyl)carbodiimide, $5 \mu \mathrm{l}, 36.7 \mu \mathrm{mol})$ was added and the solution stirred at room temperature for $2.5 \mathrm{~h}$. Then, water $(5 \mathrm{ml})$ was added and the resulting solution loaded on a $\mathrm{C}_{18}$ Waters SepPak $(5 \mathrm{~g})$ which was washed with cupious amount of water. The product was eluted with acetonitrile containing a drop of trifluoroacetic acid, the solvent removed in a stream of air and the resulting red-brown solid stored at $-80{ }^{\circ} \mathrm{C}$. The product was then dissolved in $600 \mu \mathrm{l}$ of acetonitrile and purified by semi-preparative HPLC on a HP/Agilent 1100 system with a Dynamax $300 \AA \mathrm{C}_{1}$ column using a gradient of $0.5 \%$ trifluoroacetic acid in water and acetonitrile (100:0 $\rightarrow 30: 70$ over $60 \mathrm{~min})$. The main peak was collected, the solution frozen at $-80{ }^{\circ} \mathrm{C}$, and the product lyophilized to dryness. The resulting red-brown solid was dissolved in water $(2 \mathrm{ml})$ and kept at $-80{ }^{\circ} \mathrm{C}$. Aliquots were taken from the thawed solution and diluted as needed. MS (ESIpos): 1093 $\left(\mathrm{M}^{+}-3 \mathrm{Cl}-2 \mathrm{H}\right)$.

\section{Literature}

[1] H. Mürner, B.A. Jackson, J.K. Barton, Inorg. Chem. 1998, 37, 3007-3012.

[2] S.L. Larson, C.M. Elliot, D.F. Kelley, J. Phys. Chem. 1995, 99, 6530-6539.

[3] E.H. Yonemoto, G.B. Saupe, R.H. Schmehl, S.M. Hubig, R.L. Riley, B.L. Iverson, T.E. Mallouk, J. Am. Chem. Soc. 1994, 116, 4786-4795.

[4] A. Marcinek, M.S. Platz, S.Y. Chan, R. Floresca, K. Rajagopalan, M. Golinski, D. Watt, J. Phys. Chem. 1994, 98, 412-419.

[5] J.L. Everett, J.J. Roberts, W.C.J. Ross, J. Chem. Soc. 1953, 2386-2392.

[6] W.B. Davis, J.J. Roberts, W.C.J. Ross, J. Chem. Soc. 1955, 890-895.

[7] W.C.J. Ross, G.P. Warwick, J.J. Roberts, J. Chem. Soc. 1955, 3110-3116. 